\title{
Hrvatski pomorci na brodovima u međunarodnoj plovidbi sklopili nacionalni kolektivni ugovor (2019. - 2020.)
}

\section{Croatian Seafarers on Board Ships in the International Shipping Trade Signed the National Collective Agreement (2019 - 2020)}

\author{
Marinko Đ. Učur \\ University Professor and Scientific Adviser \\ Rijeka \\ e-mail: marinko.ucur051@gmail.com
}

\begin{abstract}
Sažetak
U Narodnim novinama (dalje: NN) br. 119/2018 od 28. 12. 2018. objavljen je Nacionalni kolektivni ugovor za hrvatske pomorce na brodovima u međunarodnoj plovidbi (2019. - 2020.). Zaključen je 10. prosinca 2018. godine između Hrvatske udruge brodara Mare Nostrum (Zagreb, Avenija V. Holjevca 20) i Sindikata pomoraca Hrvatske, člana Međunarodne federacije transportnih radnika (ITF) iz Rijeke (Središnji ured, Fiorello La Guardia 13). Primjenjuje se od 1. siječnja 2019. godine. Nacionalni kolektivni ugovor za hrvatske pomorce na brodovima u međunarodnoj plovidbi (2019. - 2020.) ima sve nomotehničke oznake (karakteristike) autonomnog propisa: poštovanje objektivnih pretpostavki njegova donošenja, potpisivanja i objavljivanja (pravna osnova, nadležnost subjekata, ime (naziv), postupak donošenja (sklapanja) „u dobroj vjeri radi promicanja i održavanja socijalnog dijaloga i skladnih odnosa između Poslodavaca - Brodara i Sindikata koji se temelje na obostranom uvažavanju interesa i prava Poslodavaca - Brodara i Pomoraca", određena vremenska i prostorna vrijednost te sadržaj u skladu sa zakonima i drugim propisima na snazi, raspoređen u „ugovorni i normativni dio“ u 43 članaka (s naslovima) te "Opći dodatak“ ( $i$ „Poseban dodatak“). Sastavljen je „na hrvatskom i engleskom jeziku, a u slučaju neusklađenosti hrvatskog i engleskog teksta, za njegovo tumačenje i primjenu mjerodavan je hrvatski tekst". U ovom radu piše se o bitnim i karakterističnim oznakama ovoga autonomnog propisa.
\end{abstract}

\section{Summary}

In the Official Gazette (hereinafter: NN) No. 119/2018 of 28 December 2018 the National Collective Agreement for Croatian Seafarers on Board Ships in the International Shipping Trade was published (2019-2020). The Agreement was entered into on 10 December 2018 between the Association of Croatian Shipowners Mare Nostrum (Zagreb, Av. V. Holjevca 20) and the Seafarers' Union of Croatia, member of the International Transport Workers' Federation (ITF) from Rijeka (Head Office, Fiorello La Guardia 13). It is applied as of 1 January 2019. The National Collective Agreement for Croatian Seafarers on Board Ships in the International Shipping Trade (2019-2020) has all the nomotechnical features (characteristics) of an autonomous regulation: compliance with objective prerequisites for introducing it, signing and publishing it (legal basis, jurisdiction of the contracting parties, name (title), procedure of introducing it "in good faith to promote and maintain the social dialogue and harmonious relations between the Employers - Shipowners and Trade Unions based on mutual respect for the interests and rights of the Employers - Shipowners and Seafarers", relevant period and area wherein it may apply, as well as the content pursuant to the laws and other standing rules and regulations, consisting of the "contractual and normative part" in 43 articles (with titles) and "General Addendum" (and "Special Addendum"). It has been written "in Croatian and in English", whileas should there be any ambiguities due to textual differences in the two languages, the Croatian text shall apply". This paper elaborates on the essential and characteristic features of this autonomous regulation.
DOI 10.17818/NM/2019/3.10

UDK 347.79:656.61

Professional paper / Stručni rad

Rukopis primljen / Paper accepted: 14. 2. 2019.

\author{
KLJUČNE RIJEČI \\ Kolektivni ugovor \\ pomorci \\ međunarodna plovidba \\ Sindikat pomoraca Hrvatske \\ brodari
}

\section{UVOD / Introduction}

Nacionalni kolektivni ugovor za hrvatske pomorce na brodovima u međunarodnoj plovidbi (2019. - 2020.) (dalje: Kolektivni ugovor) primjenjuje se od 1. siječnja 2019. godine (čl. 43.), a objavljen je u NN, 119/18. Zaključen je 10. prosinca 2018. godine.

Ima originalan i specifičan sadržaj, sastavljen, potpisan i objavljen sa zadanim (propisanim i verificiranim) nomotehničkim oznakama, o uvjetima rada hrvatskih pomoraca na brodovima u međunarodnoj plovidbi. To se posebno odnosi na: značenje izraza („za potrebe kolektivnog ugovora“); primjenu "na sve hrvatske pomorce ili pomorce državljane Republike Hrvatske koji imaju boravište (rezident) ili prebivalište u Republici Hrvatskoj, a koji plove na Brodovima u međunarodnoj plovidbi upisanim u hrvatski ili neki drugi upisnik Brodova"; zaposlenje - zaključivanje ugovora o zaposlenju; obavljanje poslova lučkih 
radnika od strane posade; naknadu za posebno mjerljive radove; ukrcanje i trajanje ukrcanja; prekovremeni rad; blagdane; razdoblje odmaranja; plaću; obiteljsku doznaku; godišnji odmor; držanje straže; sastav i broj članova posade broda; nepotpunu postavu posade; plovidbe u ratnim /visoko rizičnim područjima; stvari u vlasništvu pomoraca; prestanak zaposlenja; repatrijaciju; doprinos za obvezna osiguranja pomoraca; troškove liječenja pomoraca; bolovanje; materinstvo; invaliditet; gubitak života/ smrt u službi; pokriće osiguranjem i jamstvo; prehranu, smještaj, posteljinu, udobnost itd.; sredstva osobne zaštite na radu; brodski odbor za sigurnost; komunikaciju i informiranje članova posade broda; fond solidarnosti i naknade; jednakost; postupke po prigovoru; ništavost odricanja od prava; postupanje protivno kolektivnom ugovoru; mjerodavno pravo i rješavanje sporova.

lako u navedenim pitanjima iz sadržaja Kolektivnog ugovora ima i "ugovorenih odredbi“ koje se odnose na subjekte - potpisnike, "ugovorni dio" čine odredbe o: izmjenama i dopunama Kolektivnog ugovora; trajanju Kolektivnog ugovora; nadzoru primjene; evidentiranju i odobrenju Kolektivnog ugovora; primjeni Kolektivnog ugovora na ugovore o zaposlenju; početak primjene Kolektivnog ugovora.

\section{SUBJEKTI KOLEKTIVNOG UGOVORA / Parties to the collective agreement}

Subjekti - potpisnici Kolektivnog ugovora jesu:

1. Hrvatska udruga brodara Mare Nostrum, Zagreb, uime poslodavaca kao njihova udruga (dale: Udruga);

2. Sindikat pomoraca Hrvatske, član Međunarodne federacije transportnih radnika (ITF), sa sjedištem Središnjeg ureda u Rijeci, uime radnika - pomoraca na brodovima u međunarodnoj plovidbi.

Navedeni subjekti reprezentativni su u ovoj "grani" (djelatnosti) u razvijenim odnosima udruživanja, što je rezultiralo oblikovanjem i potpisivanjem ovoga Kolektivnog ugovora. To je nastavak duge i složene suradnje navedenih subjekata jer su i do sada zaključivali odgovarajuće kolektivne ugovore u specifičnoj međunarodnoj plovidbi, uvažavajući posebnosti brodara, brodova, pomoraca - članova posade broda, ali i specifičnosti Sindikata pomoraca Hrvatske i njegova članstva u ITF-u (International Transport Workers' Federation) sa sjedištem u Londonu.

Subjekti ovoga Kolektivnog ugovora legalni su i legitimni za njegovo zaključivanje (potpisivanje) nakon što su osnovani, organizirani i registrirani te nakon što realiziraju djelatnosti. ${ }^{1}$

Kolektivni ugovor definiran je, uz druge elemente, i subjektima njegova zaključivanja i potpisivanja pored njegova imena i datuma potpisivanja, objavljivanja i početka primjene (članak 1., st. 1., pod. b). Potpisnici - subjekti ovoga Kolektivnoga ugovora nisu poslodavci u smislu Zakona o radu (i drugih zakona) i ovoga Kolektivnog ugovora.

\subsection{Subjekti u ugovoru o zaposlenju / Parties to the Employment Agreement}

U Kolektivnom ugovoru ne koristi se pojam ugovor o radu, već ugovor o zaposlenju. Subjekti ugovora o zaposlenju jesu: pomorac, ,bilo koja osoba koja je zaposlena ili uzeta u službu ili koja radi u bilo kojem svojstvu na brodu na koji se primjenjuje ovaj Kolektivni ugovor i MLC (Konvencija o radu pomoraca

'Zakon o radu. NN, 93/14, 127/17; Zakon o reprezentativnosti udruga poslodavaca i sindikata. NN, 93/14, 26/15; Pomorski zakonik. NN, 181/04 do 26/15; Učur, Marinko (2003). Radnopravni status pomoraca. Rijeka: Pravni fakultet. usvojena na Glavnoj konferenciji Međunarodne organizacije rada (ILO) održanoj 23. veljače 2006. godine i kako je dopunjena 2014. godine" (čl. 1., st. 1., pod. a, g); ${ }^{2}$ te Poslodavac, ,znači osobu koja je zaključila Ugovor o zaposlenju s Pomorcem“ (čl. 1., st. 1., pod. j).

"Ugovor o zaposlenju znači ugovor o zaposlenju kojeg na temelju Kolektivnog ugovora zaključuje Poslodavac s Pomorcem i koji je izjednačen sa pojmom ugovora o radu iz Pomorskog zakonika" (čl. 1., st. 1., pod. d). ${ }^{3}$

Preciziranje pojmova "Poslodavac" i „Pomorac" kao subjekata radnog odnosa, prema ugovoru o zaposlenju, daju druge odredbe ovoga Kolektivnog ugovora, posebno u čl. 1. i 2., uz pojmove "poseban dodatak", "članica... Udruge", "Lista Brodova“, ,Pomorac" i dr.

Odredbe Kolektivnog ugovora primjenjuju se neposredno. Međutim, za njegovu primjenu u propisanim situacijama i pitanjima potrebno je „identificirati“ Poslodavca, Brod i Pomorca prema određenim pojmovima iz "Posebnog dodatka“ („članica“, "poslodavac“, ,"članovi posade brodova“, ,Lista brodova“ i dr.).

Smatra se poslodavcem samo ona osoba "koja je zaključila ugovor o zaposlenju s Pomorcem“ (čl. 1., st. pod. j), a mora biti označen u ugovoru („Naziv i adresa Poslodavca i Brodara te brojeve njihovih telefona, faksova i elektroničke pošte") (čl. 3., st. 4. b). To je i sadržaj „Posebnog dodatka“ Kolektivnom ugovoru "koji obvezuje samo članicu potpisnicu Posebnog dodatka i Poslodavca“ (čl. 1., st. 1. f). „Brodovi“ su mjesto rada i moraju u ugovoru biti označeni („upisnik u koji je brod upisan“ u međunarodnoj plovidbi) i navedeni („Lista Brodova“) u "Posebnom dodatku“, a "koji su izravno ili putem svojih ovisnih društava u vlasništvu hrvatskih Brodara u odnosu na koje je zaključen ITF/SPH Poseban ugovor" (čl. 2., st. 2.).

Posloprimac (radnik) je, prema ovom Kolektivnom ugovoru, „hrvatski pomorac ili pomorac državljanin Republike Hrvatske, koji ima boravište (rezident) ili prebivalište u Republici Hrvatskoj, a koji plovi na Brodovima u međunarodnoj plovidbi upisanim u hrvatski ili neki drugi upisnik Brodova" (čl. 2., st. 1.). Iz sadržaja odredbi čl. 2. može se zaključiti da posloprimac (radnik) u smislu ovoga Kolektivnog ugovora može biti i „pomorac državljanin ostalih država članica Europske unije" na koje se Kolektivni ugovor primjenjuje „vodeći računa o primjeni odredaba Uredbe (EZ) br. 883/2004 Europskog parlamenta i Vijeća od 29. travnja 2004. o koordinaciji sustava socijalne sigurnosti" ${ }^{\prime 4}$.

Kako je navedeno, ugovor o zaposlenju (ugovor o radu) u vezi je s brodom koji je kod Poslodavca „klasificiran za plovidbu u međunarodnoj plovidbi“ pa je za „trajanja“ ovog Kolektivnog ugovora moguća promjena („izvan plovidbe“ i „u plovidbi“) broda.

Na temelju ovoga Kolektivnog ugovora članica udruge Mare Nostrum potpisuje "Posebni dodatak" sa Sindikatom pomoraca Hrvatske (SPH) kojim se utvrđuje da se Kolektivni ugovor treba primjenjivati na posade brodova prema "Listi brodova" s ovim sadržajem: "broj", ,"brod“, "zastave“, "Lloyd br.", "sl. broj., "Luka upisa“, „Datum upisa“, ,"GT", "Snaga mot. HP“, „Registrirani vlasnik" (a mogu biti za prijevoz rasutih tereta, tankeri, brodovi za prijevoz kemikalija i plina i drugi, s točno određenim brojem i sastavom posade broda).

${ }^{2}$ Konvencija MLC, MOR-a br. 186 o radu pomoraca iz 2006. NN, MU, 11/09.

${ }^{3}$ Pomorski zakonik - cit. o posadi broda: čl. 125. - 164.

${ }^{4}$ Zakon o provedbi uredbi EU o koordinaciji sustava socijalne sigurnosti. NN, 54/13. 


\subsection{Zaposlenje / employment}

U odredbama čl. 3. Kolektivni ugovor pod nazivom „zaposlenje“ uređuje: zaključivanje ugovora o zaposlenju; trajanje; sadržaj; liječnički pregled kao poseban uvjet za sklapanje ugovora o radu i rad člana posade broda; naknadne troškove; valjanost svjedodžbe i drugih dokumenata, obveze i odgovornost pomorca.

Ugovor o zaposlenju ima osnovu i okvir u Konvenciji o radu pomoraca (MLC, 2006., 2014.), Pomorskom zakoniku, Zakonu o radu i ovom Kolektivnom ugovoru. Uvažava se činjenica da brodovi i pomorci (članovi posade na brodu) plove po svim morima svijeta, a u skladu s općepriznatim običajima i načelima plovidbe na moru. ${ }^{5}$

„Odredbe Kolektivnog ugovora kojima se uređuju prava pomoraca primjenjuju se kao opće odredbe i na pojedinačne Ugovore o zaposlenju zaključene između Poslodavca i Pomorca. U slučaju proturječja između općih odredaba i pojedinačnog Ugovora o zaposlenju primjenjuju se opće odredbe, ako su povoljnije za pomorca. Odredbe Kolektivnog ugovora se primjenjuju i u slučaju kad pojedinačni Ugovor o zaposlenju nije zaključen u pisanom obliku (čl. 2., st. 5.). ${ }^{6}$

Sadržaj ugovora o zaposlenju („zahtjevi i uvjeti“) određen je Pravilom 2. 1. („Ugovori o zaposlenju pomoraca“) MLC-a i odredbama čl. 15. Zakona o radu, a u vezi s čl. 14., st. 6. toga Zakona (obvezna registracija ugovora o radu pri nadležnom uredu državne uprave). ${ }^{\text {? }}$

„Radni odnos je dobrovoljno, sporazumno, uređeno i osnovano, neposredno obavljanje posla (poslova) od posloprimca (radnika), koji se obvezao na određenom mjestu, kroz određeno (neodređeno) vrijeme, kao zanimanje i uz plaću raditi na sredstvima koja nisu njegovo vlasništvo". Pomorac obavlja rad na brodu (registriran i određen), kao član posade broda u službi poslodavca na temelju ugovora o zaposlenju (ugovora o radu). „Posadu broda čine osobe ukrcane za obavljanje poslova na brodu i upisane u popis posade", a "za obavljanje poslova kojima se osigurava plovidba brod mora imati odgovarajući broj članova posade...."

Na temelju ugovora o zaposlenju slijedi postupak ukrcanja pomorca na određeni brod. Ukrcanje je akt kojim se daje pravo pomorcu (posloprimcu, radniku) da boravi i radi na tom plovnom objektu i da obavlja ugovorom određene poslove člana posade. Formalni je akt ukrcanja „upis" pomorca u popis posade broda. ${ }^{9}$

„Ako tijekom ukrcanja Pomorac promijeni svojstvo u odnosu na svojstvo u kojem je bio ukrcan Poslodavac mora sa Pomorcem zaključiti novi ugovor o zaposlenju pri čemu se ne mijenja ugovoreno trajanje ukrcanja osim ako se Poslodavac i Pomorac ne dogovore drugačije" (čl. 3., st. 1.).

\subsubsection{Zaključivanje ugovora o zaposlenju / Conclusion of the Employment Agreement}

U odredbama čl. 3., st. 3. utvrđeno je da se ugovor o zaposlenju zaključuje na:

a) „neodređeno vrijeme ili

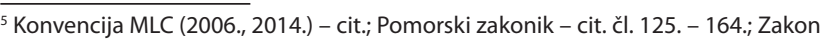
o radu - cit. čl. 14. i 15.

${ }^{6} \mathrm{U}$ pitanju je hijerarhija propisa (u ovom slučaju odnos Kolektivnog ugovora i ugovora o zaposlenju (o radu) te primjena načela in favorem laboratores). $V$. odredbe Zakona o radu - cit. čl. 9., st. 3.

${ }^{7}$ Učur, M. (1996)., Registracija ugovora o radu pomoraca i ribara“. Pomorski zbornik, Vol. 34, No. 1, pp. 193-211.

${ }^{8}$ Pomorski zakonik - cit. čl. 125. - 164

${ }^{9}$ Učur, M. (1988). „Karakteristični radni i socijalni kriteriji i mjerila za ostvarivanje prava i dužnosti pomoraca". Čovjek na brodu. Rijeka: Fakultet za pomorstvo i saobraćaj, pp. 155-170. b) određeno vremensko razdoblje koje se utvrđuje u Posebnom dodatku (3), a koje ne može biti duže od 6 mjeseci koje se po izboru Poslodavca može skratiti na 5 mjeseci ili produžiti na 7 mjeseci, ovisno o zahtjevima plovidbe, ekonomičnosti zamjene posade ili drugim opravdanim okolnostima, ako u Posebnom dodatku (3) za pojedine slučajeve nije drukčije ugovoreno ${ }^{10} \mathrm{ili}$

c) jedno ili više putovanja koja ne mogu trajati duže od ukupno 7 mjeseci, osim za vježbenika kada se Ugovor o zaposlenju može zaključiti i na rok do 12 mjeseci" (i ovo je jedan od izuzetaka u sklapanju ugovora o radu na određeno vrijeme i predstavlja specifičnost u radnim odnosima pomoraca). ${ }^{11}$

Odredbama čl. 3., st. 4. Kolektivni ugovor utvrđuje koje odredbe "mora sadržavati“ ugovor o zaposlenju. Tako pored onog sadržaja koji čini pisani ugovor o radu, iz čl. 15. Zakona o radu to su i ovi sadržaji:

- broj putovnice, broj pomorske knjižice te mjesto i datum posljednjeg liječničkog pregleda;

ime Broda na kojem će Pomorac ploviti, Međunarodna pomorska organizacija (INO), broj Broda, luka upisa i zastava Broda (jer vlasništvo broda nije obvezno u vezi s Poslodavcem), bez obzira na to što Poslodavac plovi, odnosno vije hrvatsku ili drugu zastavu;

svojstvo u kojem je Pomorac zaposlen;

pravo na prekid Ugovora o zaposlenju;

pogodnosti zaštite zdravstvene i socijalne sigurnosti koje Brodovlasnik predviđa za Pomorca;

pravo Pomorca na repatrijaciju i dr. ${ }^{12}$

$U$ vezi s ugovorom o zapošljavanju, prema Kolektivnom ugovoru, jesu i ove odredbe (pitanja i odnosi):

„mora biti dostupan radi provjere vlastima, predstavnicima sindikata i ITF-a u lukama ticanja Broda...";

liječnički pregled pomorca "kod ovlaštenog liječnika po izboru Poslodavca, pri čemu će se voditi računa o prebivalištu Pomorca“ u slučaju da „Pomorcu ističe valjanost liječničke svjedodžbe prije ukrcanja na Brod ili bi mogao isteći za vrijeme trajanja ukrcaja...";

redovita kontrola zdravstvene sposobnosti i „izvanrednog" dodatnog liječničkog pregleda "na trošak Poslodavca“;

dosljedno poštivanje odredbi („pravila“) MLC-a (troškovi viza, troškovi „pronalaska zaposlenja“; uvid u ugovor o zaposlenju i „traženje savjeta prije zaposlenja i upućivanje na ukrcanje";

brodar snosi troškove koje ima pomorac za izdavanje svjedodžbe "o priznavanju svjedodžbe o osposobljavanju“ u slučaju „promjene zastave broda“;

- "ponovno“ zapošljavanje pomoraca... „iskrcanih zbog zdravstvenih razloga";

obveza je pomorca održavati „valjanost svjedodžbi o osposobljenosti" te "dopunskoj osposobljenosti i svih drugih dokumenata", shodno posebnom propisu, uz obvezu da Poslodavcu nadoknadi štetu ako „zbog toga nastane trošak za Brodara“. ${ }^{13}$

\footnotetext{
${ }^{10}$ Usp. Zakon o radu - cit. čl. 12. i 13. Prema „Posebnom dodatku (3)“, Poslodavac i sindikat utvrđuju "trajanje ukrcanja“ i preciziraju kriterije: „zahtjevi plovidbe“ (trajanje plovidbenog zadatka); ekonomičnost zamjene posade, odnosno "druge opravdane okolnosti“" (što objektivnije i preciznije).

${ }^{11}$ Učur, M. (2003). Radnopravni status pomoraca. Rijeka: Pravni fakultet.

${ }^{12}$ Kolektivni ugovor - cit. čl. 3.

${ }^{13}$ Ibid.; Pravilnik o zvanjima i svjedodžbama pomoraca. NN, 130/13 do 12/16.
} 


\subsubsection{Ukrcanje i trajanje ukrcanja / Signing-on and duration} of employment

Prava i obveze poslodavca i radnika - pomorca na temelju ugovora o zaposlenju teku od dana ukrcaja, odnosno od dana (sata) putovanja iz Hrvatske ako se brod na koji se Pomorac treba ukrcati nalazi izvan teritorijalnih voda Republike Hrvatske. U tom slučaju Poslodavac snosi troškove prijevoza, smještaja i prehrane Pomorca tijekom putovanja iz mjesta (iz Hrvatske) do luke ukrcaja (gdje se brod nalazi).

To je uređeno u odredbama čl. 6. ovoga Kolektivnog ugovora. Određenje je u st. 1. ovoga članka da Pomorac ima prava i obveze „od dana započinjanja putovanja radi ukrcanja na Brod do trenutka ukrcanja“. To su dvije bitne "točke": započinjenje putovanja i trenutak ukrcanja. Bolje je tumačiti i jedno i drugo jednako od „trenutka započinjenja putovanja... do trenutka ukrcanja“. Ukrcanje je čin „stupanja“ na Brod, na radno mjesto te spremnost obavljanja poslova i zadataka prema uputi Poslodavca i pravilima struke. To je „prvi čin“ nakon legalno sklopljenog ugovora o zaposlenju, čija realizacija započinje upravo „započinjanjem putovanja“ u svrhu ukrcanja na brod. $\mathrm{Ne}$ moraju se „podudarati“ dan zaključenja ugovora o radu s danom započinjanja putovanja, odnosno dana ukrcanja. To mogu biti, a u praksi i jesu, tri različita vremena. Od dana zaključivanja ugovora o zaposlenju (ugovora o radu) do „započinjanja putovanja radi ukrcanja na brod mogu se "dogoditi“ različite situacije (pa može doći i do "nerealizacije“ ugovora (u skladu s općim propisima o građanskim pravnim odnosima). ${ }^{14}$

Za sve vrijeme "od dana započinjanja putovanja radi ukrcanja na brod do trenutka ukrcanja" Pomorac ima pravo na plaću i dnevnicu, „uz zadovoljavanje svih razumnih zahtjeva udobnosti tijekom putovanja".

U st. 2. ovoga članka, a u interesu zaštite zdravlja i sigurnosti na radu pomoraca i sigurnosti plovidbe, uređeno je pitanje „preuzimanja dužnosti na brodu“ od pomoraca "ukoliko ukrcanje na brod slijedi nakon dugog putovanja". Obveza je Poslodavca da, "koliko god to prilike dopuštaju“, o tome vode računa "da Pomorac odmoran preuzme dužnost na brodu“.

Ukrcanje (rad na brodu u svojstvu člana posade broda) može trajati („vremensko razdoblje“) „od najviše 9 mjeseci tijekom bilo kojih 12 mjeseci“. To ovisi „o zahtjevima plovidbe, području plovidbe i tipu broda“ (čl. 6., st. 3.). To se ne odnosi na ukrcanje vježbenika „,koji mogu biti ukrcani do najdulje 12 mjeseci" (st. 4.). Detaljnije to uređuje Poslodavac u „Posebnom dodatku (3), kao dodatku Kolektivnom ugovoru koji obvezuje samo članicu potpisnicu Posebnog dodatka i Poslodavca" (čl. 6. u vezi s čl. 1., st. 1. pod. f).

Iskrcanje s broda čin je prestanka (de facto) obavljanja službe na brodu u svojstvu člana posade. To je čin prestanka ukrcanja, što treba urediti $i$ „,Posebnim dodatkom (3)" (kod članice i Poslodavca), $i$ to „prvim uplovljavanjem broda u luku sukladno Ugovoru o zaposlenju" (čl. 6., st. 5.).

Trajanje ukrcaja duže od ugovora, "osim ako je do propusta došlo bez krivnje poslodavca ili iz razloga na koje ne utječe Poslodavac...", ima za posljedicu pravo Pomorca "na redovitu plaću i na mjesečni dodatak u iznosu njegove osnovne plaće za cijelo razdoblje produljenog ukrcanja na brodu u odnosu na ugovorno razdoblje." Pravo na ovu naknadu nema Pomorac, bez obzira na "produljeno ukrcanje" ako je on to "izričito zahtijevao", a Poslodavac prihvatio (čl. 6., st. 6. i 7.).

${ }^{14} \mathrm{~V}$. Zakon o obveznim odnosima. NN, 35/05 do 78/15 u vezi s čl. 8. Zakona o radu. $N N, 93 / 14,127 / 17$
2.2.3. Obavljanje poslova lučkih radnika i posebno mjerljivih radova članova posade / Carrying out work done by dockers and supplementary work of the crew

U čl. 4. uređeno je pitanje "obavljanje poslova lučkih radnika od strane posade", a u čl. 5. "Naknada za posebno mjerljive radove".

Obavljanje plovidbenog zahvata (,pothvata“) podrazumijeva ne samo plovidbu već i druge "operacije", pa i one u luci na ukrcaju, odnosno iskrcaju broda. U tome sudjeluju i članovi posade broda i lučki radnici. Lučki radnici obavljaju lučke operacije, i to u pravilu u

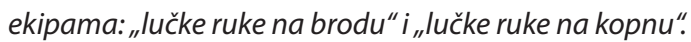

"Od brodske posade se ne očekuje niti od nje poslodavac može zahtijevati da rukuje teretom niti da obavlja ostale poslove koje tradicionalno i povijesno obavljaju lučki radnici, bez prethodnog dogovora sa ITF sindikatom lučkih radnika i to pod uvjetom da Pomorci pojedinačno pristanu obavljati te poslove za koje će tada primiti naknadu" uređenu ovim odredbama (u redovitom radnom vremenu i izvan njega). Posebne zabrane obavljanja poslova lučkih radnika donose se kada su oni u štrajku ili drugom obliku industrijske akcije u organizaciji ITF-a lučkih radnika u luci u kojoj se ta industrijska akcija ostvaruje dok brod boravi u toj luci. Bitno je da industrijska akcija lučkih radnika nije nezakonita. ${ }^{15}$

Dosta je poslova koje treba obaviti na brodu kao plovnom objektu („tekuće održavanje“ koje u pravilu obavljaju "neovisni ugovaratelji“ (brodogradilište, serviseri i sl.). Te poslove, koji ne spadaju u "redovite poslove“ članova posade broda, ovi mogu obavljati prema „pisanom dogovoru“ s poslodavcem (naknada, rok izvršenja i dr.). ${ }^{16}$

\section{KARAKTERISTIČNA PITANJA RADNIH ODNOSA / Main topics of interest in employment}

Kolektivni ugovor uređuje ova pitanja i odnose u radnom odnosu pomoraca: radno vrijeme; prekovremeni rad; blagdani; razdoblje odmaranja; plaća; obiteljska doznaka; godišnji odmor; držanje straže; sastav i broj članova posade broda; nepotpuna postava posade; plovidba u ratnim/visoko rizičnim područjima; stvari u vlasništvu pomorca; prestanak zaposlenja; repatrijacija; prehrana; smještaj; posteljina; udobnost itd.; sredstva osobne zaštite na radu; jednakost; ništavost odricanja od prava.

Pored činjenice da se radi o pravima koja uređuje Zakon o radu za sve radnike u radnom odnosu, ovdje se naglašavaju samo specifičnosti tih prava kako ih uređuje ovaj Kolektivni ugovor.

\subsection{Radno vrijeme, prekovremeni rad, blagdani, odmori / Hours of duty, overtime, public holidays, rest periods}

„Redovito radno vrijeme za sve Pomorce iznosi 8 sati dnevno od ponedjeljka do petka, uključujući oba navedena dana, što ukupno iznosi 40 sati tjedno ili 173 sata prosječno mjesečno" (čl. 7.). U Kolektivnom ugovoru nema odredbi o "pripravnosti“ i "poslovima po pozivu poslodavca", puno radno vrijeme određuje se kao "redovito“; nema "nepunog radnog vremena", niti "skraćenog radnog vremena", a raspored određuje poslodavac, odnosno zapovjednik broda.

Prekovremeni je rad "svaki rad na dužnosti preko 8 sati", a „najmanje 103 zajamčena sata prekovremenog rada". Označava poseban uvjet rada i u Kolektivnom ugovoru reguliran je

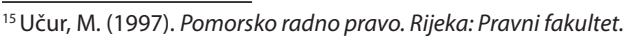

${ }^{16}$ Pravilnik o uvjetima i načinu održavanja straže te obavljanju drugih poslova na brodu kojima se osigurava sigurna plovidba i zaštita mora od onečišćenja. NN $125 / 05$ do $29 / 16$
} 
specifično, u skladu s „ovlastima“ iz čl. 65., st. 4. Zakona o radu. ${ }^{17}$

Zakon o radu "veže" prekovremeni rad za "prijeku potrebu“, a Kolektivni ugovor utvrđuje da je prekovremeni rad pomoraca "standard" koji se javlja "na dužnosti preko 8 sati“ i koji se plaća, a da se ne plaća "kao prekovremeni rad... sati rada za vrijeme opasnosti". Ta posebnost u vezi je sa stražama i rasporedom radnog vremena, odnosno s opasnošću propisanom čl. 8., st. 4. Kolektivnog ugovora.

U čl. 8. uređena su i ova pitanja: satnica za prekovremeni rad iznosi 1,25 „od satnice osnovne plaće za svako određeno zvanje na brodu i tjedne sate rada" (to znači da niti jedan član posade bez obzira na zvanje nije „isključen" od prekovremenog rada); „Posebnim dodatkom (2)“ kod Poslodavca „svakom Pomorcu se mjesečno plaća najmanje 103 zajamčenih sata prekovremenog rada..."; podatke „ovjerava zapovijednik ili od njega ovlaštena osoba i Pomorac" svaki mjesec (a pravo je Pomorca da "u bilo koje vrijeme trajanja ugovora o zaposlenju“ traži „ispis njegove evidencije o prekovremenom radu").

Prema čl. 8., st. 4., Kolektivni ugovor propisuje da "kao prekovremeni rad ne plaćaju se sati rada za vrijeme opasnosti koja izravno utječe na neposrednu sigurnost Broda, njegovih putnika i posade, o čemu isključivo prosuđuje zapovjednik". Ne plaća se kao prekovremeni rad: „prigodom vježbe spuštanja čamaca za spašavanje, te rad potreban radi pružanja pomoći drugim brodovima ili osobama kojima neposredno prijeti pogibelj; vježbe gašenja požara te vježbe propisane INO standardima.....18

U odredabama čl. 9. Kolektivni ugovor uređuje pitanje blagdana, stoga su oni navedeni u „Općem dodatku (1)“ i „za brodove s većinskom ili isključivo hrvatskom posadom... i smatraju se blagdanima za vrijeme plovidbe broda i u luci". Pomorac koji radi na dan blagdana ima pravo „na naknadu plaće utvrđenu Posebnim dodatkom (2) kod Poslodavca, ali ne manje od satnice koja se plaća za prekovremeni rad". ${ }^{19}$

„Razdoblje odmaranja“ naslov je čl. 10. u kojem se uređuje:

obvezno osiguranje "najmanje 10 sati odmora u svakom razdoblju od 24 sata i 77 sati u bilo kojem razdoblju od 7 dana" (riječ je o odmoru između dva radna vremena („straže"), odnosno tjednom odmoru). Određeno je kako se računa "početak razdoblja” od 24 sata („kad Pomorac otpočne s radom neposredno nakon što je imao najmanje 6 neprekidnih sati odmora"). Odmor može biti podijeljen na dva dijela, a razmak "ne može prelaziti 14 sati“. Jedan dio odmora "mora trajati najmanje 6 neprekidnih sati". O rasporedu odmora odlučuje poslodavac i objavljuje ga na ploči („na vidljivom mjestu“, na hrvatskom i na engleskom jeziku". Propisani su razlozi u kojima zapovjednik odlučuje da Pomorac "prekine“ odmor, uz obvezu „"čim to bude moguće“ osigurati vrijeme odmora" zbog posebno propisanih vježbi. ${ }^{20}$

\footnotetext{
${ }^{17}$ Zakon o radu ograničava prekovremeni rad na 250 sati godišnje, a Kolektivn ugovor "najmanje 103 zajamčenih sati prekovremenog rada“ mjesečno (čl. 8., st. 2.). ${ }_{18}$ Međunarodna konvencija o zaštiti ljudskog života na moru (1974). NN, MU 13/99, 4/00; Zakon o potvrđivanju konvencije o radu pomoraca iz 2006. godine. $N N$ MU, 11/09; Zakon o potvrđivanju Međunarode konvencije o nadzoru i upravljanju brodskim balastnim vodama i talozima. NN, MU, 3/10.

${ }^{19} V_{i d i}$,Opći dodatak (1)“ uz Kolektivni ugovor; Zakon o blagdanima, spomendanima i neradnim danima u Republici Hrvatskoj. NN, 33/96 do 130/11.

20 "Prekid" odmora može, prema odluci zapovjednika, uslijediti zbog "slučaja opasnosti koje utječu na neposrednu sigurnost broda, osoba na brodu ili tereta..

ili pomoći drugim brodovima ili osobama u pogibelji na moru“ (čl. 10., st. 5.)

Što manje trebaju smetati: smotre, vježbe gašenja požara, vježbe s čamcima za

spašavanje i druge „propisane“ vježbe (čl. 10., st. 6. Kolektivnog ugovora).
}

\subsection{Držanje straže, posada broda / Watch-keeping, manning}

Raspored pomoraca na brodu obavlja zapovjednik organizirajući rad (stražu) u tri straže „u plovidbi i na sidrištu, te prema potrebi u luci“. Prema čl. 14., st. 2., „Zapovjednik ima isključivu slobodu odlučivanja koji će Pomorci biti određeni za stražu, a koji prema potrebi za dnevni rad". U plovidbi bitan je časnik plovidbene straže, a njemu „za vrijeme mraka (u plovidbi) pomaže član plovidbene straže". U skladu s propisima o držanju straže, časniku plovidbene straže može „i u drugim slučajevima prema procjeni zapovjednika ili časnika plovidbene straže" pomagati član plovidbene straže. Stražu obavljaju svi članovi posade broda, osim zapovjednika i upravitelja stroja, a i oni drže stražu "na brodovima za opskrbu i opsluživanje naftnih i/ili plinskih platformi“ (čl. 14.).

U skladu s „Pravilom 2.7. Brojno stanje posade“ Kovencije o radu pomoraca iz 2006. godine (MLC-a), Kolektivni ugovor uređuje "sastav i broj članova posade broda s potrebnim ovlaštenjima kako bi se u svako doba omogućila sigurna plovidba i održavanje sustava u tri straže". Svaki poslodavac to utvrđuje sa sindikatom za svaki brod u „Posebnom dodatku (4)“. To je odvojeno od „radnih grupa" koje poslodavac u sporazumu sa sindikatom zapošljava na brodu „poštujući principe“ utvrđene u čl. 15., st. 3. Kolektivnog ugovora.

Ako se dogodi da brod ostane bez punog "postava posade“, posao se raspoređuje na posadu i posebno plaća, a posada se mora popuniti „prije isplovljenja broda iz prve naredne luke ticanja" (čl. 16.). ${ }^{21}$

\subsection{Plovidba u ratnim/visoko rizičnim područjima / Navigation in warlike/high risk areas}

Odredbe čl. 17. Kolektivnog ugovora uređuju vrlo specifično pitanje i odnos koji se javljaju i reguliraju samo kada su u pitanju pomorci. U ostvarenju plovidbenog pothvata nerijetko se događalo i događa se da brod mora ploviti i morima u ratnim područjima, odnosno, kako piše u navedenoj odredbi, "visoko rizičnim područjima“. U tim i takvim situacijama postupa se u skladu s aktima i odlukama tijela ITF (u Londonu) i tijela osiguravatelja (JWC), odnosno njegova "zajedničkog ratnog odbora“. U pitanju je „isključenje iz osiguranja redovitih ratnih rizika“ ili „za (područja) za koja se plaća dodatna premija za ratni rizik za brod po stopi od 0,25\%". Tako se definira "ratno i visoko rizično područje" (čl. 17., st. 1.).

U vezi s tim uređeno je sljedeće:

1. potpisnici će ovog Kolektivnog ugovora „kvartalno izmijeniti službene informacije po objavi JWC" o činjenicama bitnim za primjenu ovoga Kolektivnog ugovora;

2. Pomorac „za vrijeme ukrcaja“ mora biti obaviješten da brod za vrijeme plovidbe prolazi kroz takva područja;

3. ako brod uđe u takvo područje, Pomorac može i ima: pravo „odustati od nastavka plovidbe" s pravom na repatrijaciju i primanja do dana povratka; pravo na "dvostruku osnovnu plaću“ za svaki dan "boravka broda u takvim područjima“; „pravo na dvostruki iznos naknade za invalidnost i smrt koji su prouzročeni u tim područjima“.

U čl. 17., st. 5. uređeno je pitanje prava otetog ili zarobljenog pomorca ili "na neki drugi način spriječenog nastaviti plovidbu“ na bilo kojem području (korištenje pravom prema ugovoru i pomoć Poslodavca „sve dok ne bude oslobođen“ do završetka ugovora ili povratka kući (plaća i druga ugovorena prava).

${ }^{21}$ V. MLC: Pravilo 2.7.; Standard A. 2.7.; Smjernica B. 2.7 


\subsection{Neka druga specifična prava pomoraca / Other specific rights of seafarers}

U odredbama čl. 18., 20., 28. i 29. ovoga Kolektivnog ugovora uređena su također neka prava pomoraca koja se smatraju posebnim, odnosno specifičnim u radnim odnosima.

\subsubsection{Stvari u vlasništvu pomorca (čl. 18.) / Personal effects of seafarer (Art. 18)}

Logično je da od polaska na ukrcanje do povratka s ukrcanja pomorac ima i koristi se nužnim (neophodnim) stvarima u svom vlasništvu (neće „nositi“ umjetnička djela i opremu) te da može doći do njihova „potpunog ili djelomičnog gubitka i oštećenja... bilo za vrijeme trajanja ukrcanja ili na putovanju do i sa broda“. U tom slučaju pomorac „ima pravo na naknadu štete od Poslodavca do najvećeg iznosa navedenog u Općem dodatku (2)“, a pomorac to mora dokazati („podatke u vezi s izgubljenim stvarima" (to su samo "stvari u njegovoj osobnoj uporabi"). Prema "Dodatku (2) popis novčanih naknada", čl. 18. za "stvari u vlasništvu pomorca" jest „najveći iznos: 3000 USD, koji uključuje gotovinu do 300 USD".

Kada pomorac "napušta brod zbog bolesti ili ozljeda“, Poslodavac je dužan "poduzeti mjere čuvanja imovine Pomorca ili imovine preminulog Pomorca i vratiti iste njemu ili imenovanom korisniku“ (čl. 18., st. 2.).

\subsubsection{Repatrijacija / Repatriation}

Repatrijacija je pravo Pomorca da se nakon prestanka ukrcanja vrati u mjesto određeno ugovorom o zaposlenju (prebivalište, boravište, luka ukrcanja). Prema čl. 20. Kolektivnog ugovora, u postupku repatrijacije trebaju se primjeniti odredbe MLC-a (Konvencije o radu pomoraca, 2006.): „Pravilo 2.5. Repatrijacija, na teret Poslodavca na način da se zadovolje svi razumni zahtjevi glede udobnosti... i troškove uzdržavanja Pomorca na kopnu do završetka repatrijacije".

Repatrijacija podrazumijeva troškove na teret Poslodavca koji se sasatoje od: osnovne plaće "utvrđene Posebnim dodatkom (2)“ i dnevnice "do svog stalnog prebivališta ili do mjesta sklapanja ugovora o zaposlenju, ovisno o želji Pomorca...."

Repatrijacija se priznaje Pomorcu „u slijedećim okolnostima“: nakon isteka vremena ukrcanja22;

odlukom Poslodavca (raskid uz otkazni rok 30 dana i u nazočnosti dvojice svjedoka); potpuni gubitak broda; brod u raspremi (najmanje mjesec dana) ili ako Poslodavac proda brod (čl. 19., st. 3. Kolektivnog ugovora);

odlukom Pomorca „iz opravdanih razloga" utvrđenih u čl. 19., st. 2. Kolektivnog ugovora i preciziranih u čl. 20., st. 2 . Kolektivnog ugovora.

Pravo na repatrijaciju ima pomorac, iako je kriv „ili traži iskrcaj na vlastiti zahtjev prije isteka ugovora o iskrcanju", u kojem slučaju „Poslodavac mora izvršiti repatrijaciju pomorca o svom trošku“ s pravom na obeštećenje "od preostalog neisplaćenog dijela njegove (pomorčeve) plaće (čl. 20., st. 3.).

3.4.3. Prehrana, smještaj, posteljina, udobnost itd. / Food, accommodation, bedding, amenities, etc.

Pozivom na MLC (Konvenciju o pravu pomoraca, 2006.), u čl.

${ }^{22}$ Kolektivni ugovor: čl. 6.,"Trajanje ukrcanja“ ", Posebni dodatak (2) - platna ljestvica” utvrđuje plaće na brodovima određenog poslodavca (ugovor sklapaju Poslodava i Sindikat pomoraca Hrvatske pozivom na Kolektivni ugovor), a „Posebni dodatak (3)" trajanje ukrcanja“.
28. Kolektivni ugovor određuje obvezu Poslodavca da osigura pomorcu prehranu, smještaj, udobnost, kuhinju $\mathrm{i}$ „jednokratan poziv/vezu...".

\subsubsection{Sredstva osobne zaštite na radu / Personal protective equipment at work}

Neosporno je da zaštita zdravlja i sigurnost na radu radnika - u ovom članku pomorca - spada u temeljna ljudska prava zaštićena najvišom pravnom normom - Ustavom države („zakona nad zakonima") u skladu s univerzalnim i regionalnim vrelima prava. Tako treba tumačiti sadržaj odredbi čl. 29. Kolektivnog ugovora.

Osiguranje "sredstava osobne zaštite na radu za svakog Pomorca za cijelo vrijeme njegova boravka na brodu“ obveza je poslodavca. Kada je „potrebno... sve osobe uključene u rad i sve druge osobe koje mogu biti ugrožene... iz rada..." moraju „imati na raspolaganju i nositi“ propisana osobna zaštitna sredstva (dovoljan broj, na određenome mjestu, s atestima standardima...).

Poseban režim ima „odjeća za spašavanje“ u dovoljnom broju i zahtijevanim standardima. ${ }^{24}$

\section{PLAĆA, OBITELJSKA DOZNAKA I GODIŠNJI ODMOR / Wages, allotments and annual leave}

U odredbama čl. 11. Kolektivni ugovor uređuje plaću (kako se ugovara i obračunava ukupna plaća svakog Pomorca u međunarodnoj plovidbi; „ljestvicu“ iz Posebnog dodatka (2); kako se i kada isplaćuje; što se smatra "odbicima od plaće“; pravo Pomorca na "gotovinsku isplatu“ i druga pitanja, stoga za plaću, naknade i druga primanja „uzima se da puni mjesec ima 30 dana".

U čl. 1., st. 8. pod f. utvrđeno je: „Minimalna ukupna plaća znači ukupnost plaće s naslova redovitog radnog vremena, zajamčenog prekovremenog rada i dodatka za godišnji odmor".25

U čl. 11. Kolektivnog ugovora posebno je bitna (i karakteristična) odredba st. 1. koja glasi ovako: „Ukupna plaća svakog Pomorca na brodu u međunarodnoj plovidbi ugovara se i obračunava temeljem Kolektivnog ugovora i minimalne ukupne plaće kormilara koji ima svjedodžbu o osposobljenosti u iznosu prema tablici plaća važećeg ITF Uniform TCC Kolektivnog ugovora za posade na FOC brodovima mjesečno i to za posade na brodovima svih tipova preko 6000 BT nosivosti i/ili sa strojem porivne snage do $3000 \mathrm{~kW}$... i ne može biti niža od minimalne osnovne plaće prema Rezoluciji ILO (2016) i prema zajedničkom tumačenju ITF-a i Međunarodne brodarske federacije (ISF)". ${ }^{26}$

„Svi pomorci moraju biti plaćeni za svoj rad redovito i u potpunosti u skladu sa svojim ugovorima o zaposlenju („Pravilo 2.2. Plaće MLC Konvencije 2006.“). Ostale odredbe MLC Konvencije bitne za primjenu ovoga Kolektivnog ugovora

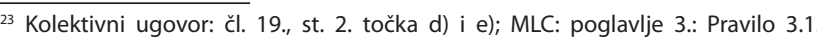
Prostorije za smještaj i Pravilo 3.2. Prehrana i posluživanje hrane (te smjernice Poglavlja 3. MLC-a).

${ }^{24}$ Kolektivni ugovor: čl. 29.; Zakon o zaštiti na radu. NN, 71/14 do 96/18; ISM kodeks, sms Pravilima i standardima Pravilo 4.3. Zaštita zdravlja i sigurnost iz Konvencije o pravima radnika 2006. (MLC-a).

${ }^{25}$ Ugovor o zaposlenju „mora sadržavati..." (pored drugih) odredbe „iznos plaće ostalih primanja Pomorca“ (čl. 3., st. 4. pod. f).

${ }^{26}$ Upućuje se na "osnove, kriterije i mjerila" koje je postavio "režim" međunarodno uređenih odnosa (konvencije - STCW; ITF; Rezolucija ILO (Međunarodne organizacije rada: Joint Maritim Commission (JMC), ISF i drugih). FOC brodov „plove“ pod „zastavama pogodnosti i tumači se da ne poštuju postavljene standarde i kriterije o plaći i drugim uvjetima rada; Međunarodna konvencija o standardu osposobljavanja, izdavanju svjedodžbi i držanju straže iz 1995. godine kako je izmijenjena i dopunjena (STCW konvencija). NN, MU, 1/92.
} 
jesu: „Standard A 2.2. Plaće; Smjernica B 2.2. Plaće, Smjernica B 2.2.1. Posebne definicije; Smjernica B 2.2.2. Obračun i isplata; Smjernica B 2.2.3. Najniže plaće i Smjernica B 2.2.4. Najmanja mjesečna osnovna plaća ili plaća obračunata za stručno osposobljene pomorce".

„Svaki pomorac na kojega se odnosi ovaj Kolektivni ugovor ima prava na isplatu obiteljske doznake u skladu sa odredbama standarda A 2 - 2. stavka 5. MLC-a“ („,prijenos cijele ili dijela zarade svojim obiteljima, osobama koje o njima ovise ili korisnicima"). ${ }^{27}$

\subsection{Godišnji odmor / Annual leave}

U čl. 13. Kolektivni ugovor uređuje godišnji odmor („plaćeni godišnji odmor") na koji ima pravo "svaki pomorac" prema "Pravilu 2.4. Pravo na odmor MLC-a".

Pravo na godišnji odmor koristi se nakon iskrcanja „iz bilo kojeg razloga“. Godišnji odmor iznosi „6 dana... za svaki puni mjesec zaposlenja”, s tim da "za prekinuta razdoblja od 15 dana i manje odobravaju se 3 dana plaćenog godišnjeg odmora, a za prekinuta razdoblja od više od 15 dana, ali manje od 30 dana odobrava se 6 dana plaćenog godišnjeg odmora".

Kao vrijeme zaposlenja računa se "od trenutka kada se pomorac zaposlio, bez obzira je li potpisao ugovor o zaposlenju ili nije, i traje sve dok se njegovo ukrcanje ne završi" (st. 3).

„Posebnim dodatkom (2)“ utvrđuje se „platna ljestvica kojoj odgovara mjesečna naknada za godišnji odmor" (st. 4.).

Godišnji odmor se u pravilu koristi nakon iskrcanja, a "tijekom trajanja ukrcanja samo ako to pomorac želi i pod uvjetom da to ne šteti plovidbi i radu broda“. Preostali se dani plaćaju („nadoknađuju se novčanim iznosom po danu“ prema navedenoj platnoj ljestvici iz Posebnog dodatka (2) (st. 6.).

„Kao dio godišnjeg odmora neće se obračunavati: blagdani („bez obzira kada padaju“, bolovanje ili majčinstvo, povremeni izlazak „na kopno... dok ugovor traje...."28

\section{SOCIJALNO-PRAVNA PITANJA I ODNOSI / SOCIAL-LEGAL ISSUES AND RELATIONS}

Kolektivni ugovor sadrži i odredbe koje se mogu kvalificirati kao "socijalnopravna pitanja i odnosi", kao što su: „Doprinos za obvezna osiguranja pomoraca“ (čl. 21.); „Troškovi liječenja pomoraca” (čl. 22.); „Bolovanje“ (čl. 23.); „Materinstvo“ (čl. 24.); "Invaliditet" (čl. 25.); „Gubitak života / smrt u službi“ (čl. 26.); „Pokriće osiguranja i jamstvo" (čl. 27.).

\subsection{Doprinos za obvezna osiguranja pomoraca / Manadatory insurance contributions}

Kolektivni ugovor "delegira" autonomnom uređivanju pri pojedinom poslodavcu (Posebni dodatak (5)) da ugovorne stranke „pregovorima utvrde u kojem će postotku Poslodavac pomorcu nadoknaditi troškove njegova plaćanja doprinosa za obvezna osiguranja“. Pri tome se moraju „ravnati“ u odnosu "na Pravilo 4.5. - Socijalno osiguranje MLC-a“ (čl. 21.). Ta pitanja uređuje Pomorski zakonik pa je pozivom na odredbe čl. 129., st. 9. donesena Naredba o mjesečnoj osnovici za obračun doprinosa za obvezna osiguranja člana posade broda u međunarodnoj plovidbi (za 2017.) (NN, 10/17).

MLC obvezuje državu (članice) da "mora osigurati da svi pomorci i, u opsegu predviđenom nacionalnim zakonom, od ${ }^{27}$ STCW konvencija 2006. - cit.; čl. 11. i 12. Kolektivnog ugovora.

${ }^{28}$ V. Zakon o radu - cit. čl. 76. - 85.; Konvencija MLC-a: „Pravilo 2.4.; Standard A 2.4. Smjernica B 2.4., B 2.4.1., B 2.4.2., B 2.4.3., B 2.4.4. koje se odnose na odmor. njima ovisne osobe, imaju pristup zaštiti socijalnog osiguranja" („Pravilo 4.5. Socijalno osiguranje....").

\subsection{Troškovi liječenja pomoraca / Seafarers' medical expenses}

Odredbama čl. 22. („Troškovi liječenja pomoraca“) Kolektivni ugovor uređuje:

poslodavac snosi „troškove liječenja, ukljućujući i bolničko liječenje Pomorca koji se iskrcao u inozemstvu zbog bolesti ili ozljeda";

poslodavac o svom trošku osigurava repatrijaciju pomorca "ako se Pomorac ne može vratiti na brod s kojeg je iskrcan"; sve do povratka u Hrvatsku, kada mu to omogući zdravstveno stanje, poslodavac plaća „troškove liječenja (pomorca) u inozemstvu“;

nakon repatrijacije „troškove liječenja zbog bolesti, podmiruje Poslodavac... do ozdravljenja, ako nisu pokriveni redovitim zdravstvenim osiguranjem... najviše 120 dana nakon repatrijacije", a ako je to posljedica ozljede na radu, troškove podmiruje Poslodavac "do najvećeg mogućeg stupnja medicinskog ozdravljenja ili njegovim proglašenjem trajnim invalidom u određenom stupnju, ako nisu pokriveni zdravstvenim osiguranjem".

\subsection{Bolovanje / Sick pay}

Najduže 120 dana nakon repatrijacije, a prije toga, dok bolest traje, poslodavac plaća pomorcu naknadu za bolovanje "u visini njegove osnovne plaće". Ako nakon toga pomorac prima naknadu "od nadležne ustanove za zdravstveno osiguranje", a ona je manja od njegove osnovne plaće, tu razliku plaća poslodavac, pod uvjetom „da Poslodavac plaća ili refundira Pomorcu doprinos za zdravstveno osiguranje u cijelosti".

Sve do izlječenja, povratka na brod ili ako je pomorac trajno nesposoban za zvanje Pomorca - a sve je to posljedica ozljede na radu (ali ne zbog namjernog samoozljeđivanja) - poslodavac isplaćuje pomorcu naknadu u visini njegove osnovne plaće.

Precizno je propisan postupak utvrđivanja bolesti, obavijest poslodavcu i prava za vrijeme bolovanja, odnosno liječenja (čl. 23.).

\subsection{Materinstvo / Maternity}

U odredbama čl. 24. Kolektivni ugovor uređuje slučaj „kada Pomorac zatrudni tijekom trajanja ugovora o zaposlenju“:

- treba obavijestiti poslodavca „čim je trudnoća potvrđena“;

- repatrirati pomorca „čim je razumno moguće u prvoj luci ticanja“, , ali ni u kom slučaju poslije 26-tog tjedna trudnoće i kada priroda putovanja Broda može biti... rizična..."; ima pravo "na 120 dana osnovne plaće";

imat će "prednost u ponovnom zaposlenju..." s poslodavcem „u popunjavanju slobodnog mjesta u istom ili odgovarajućem svojstvu unutar 3 godine nakon rođenja djeteta“ (čl. 24.).

\subsection{Invaliditet / Disability}

Propisano je pravo pomorca koji "doživi nezgodu od čijih posljedica je nastupio invaliditet $u$ određenom stupnju" da mu poslodavac isplati naknadu utvrđenu u „Općem dodatku (2) i (3) ovog Kolektivnog ugovora... za vrijeme trajanja ugovora o zaposlenju što uključuje i putovanje od njegova prebivališta do Broda i natrag" (čl. 25., st. 1.).

U čl. 25., st. 2. utvrđeno je metodom taksativnog normiranja 
kada poslodavac "nije dužan isplatiti naknadu... ako dokaže“ navedene razloge.

U ostalim odredbama utvrđuje se postupak utvrđivanja invaliditeta, visina i postupak isplate naknade, zahtjev za naknadu štete, vođenje arbitražnog ili sudskog postupka i druga pitanja (čl. 25., st. 3. - 8.).

\subsection{Gubitak života/smrt u službi / Loss of life/death in service}

„Ako pomorac za vrijeme trajanja Ugovora o zaposlenju, što uključuje i putovanje od njegova stalnog prebivališta do Broda i obrnuto, doživi nezgodu od čijih posljedica umre ili ako umre prirodnom smrću, Poslodavac je dužan isplatiti svotu navedenu u Općem dodatku (2)..., , i to točno određenim subjektima (čl. 26., st. 1.).

U st. 2. utvrđeno je kada Poslodavac „nije dužan isplatiti svotu“.

Ostale odredbe uređuju posebne naknade djeci mlađoj od 18 godina, postavljanje zahtjeva za naknadu štete nasljednicima te posljedice „proglašenja pomoraca mrtvim".29

\subsection{Pokriće osiguranjem i jamstvo / Insurance cover and warranty}

„Poslodavac će zaključiti odgovarajuće klupsko osiguranje za svoje potpuno pokriće u slučajevima proizašlim iz članaka ovog Kolektivnog ugovora" (čl. 27., st. 1.). U st. 2. utvrđuje se da je poslodavac "solidarni dužnik" za tužene (točno određene subjekte) „protiv kojih Pomorac, ili njegovi nasljednici dobiju arbitražni ili sudski spor za naknadu štete zbog ozljede ili smrti Pomorca“ i u kojem slučaju „plaća dosuđeni iznos“."30

\section{PRESTANAK ZAPOSLENJA / Termination of employment}

Odredbama čl. 15. Kolektivni ugovor regulira „prestanak zaposlenja“. Regulirana su ova dva razloga prestanka zaposlenja: „nakon isteka ugovora o zaposlenju“ i „kada je iskrcanje obavljeno zbog bolesti ili ozljede nakon liječničkog pregleda“."

U čl. 19., st. 2. reguliraju se slučajevi i osnove kada Pomorac može s Poslodavcem prekinuti zaposlenje ili tražiti iskrcanje: „pisana obavijest pomorca mjesec dana unaprijed Poslodavcu u nazočnosti dva svjedoka“. To je zapravo otkaz koji radnik daje uz utvrđeni otkazni rok; u slučaju da supružnik ili roditelj pomorca teško oboli (ili „partner Pomorca“) tijekom putovanja; „značajna izmjena obzirom na trajanje ili kategoriju plovidbe“ u slučaju ugovora na određeno vrijeme; ako brod plovi u ratno ili rizično područje; ako brod ne ispunjava standarde; ${ }^{32}$ brod pod "zaustavljanjem" 30 dana; nepoštovanje Kolektivnog ugovora. ${ }^{33}$

U st. 3. regulirana je mogućnost da Poslodavac "može raskinuti s Pomorcem ugovor o zaposlenju“: obavijest Pomorcu 30 dana unaprijed („u nazočnosti dva svjedoka“); gubitak broda, prodaja i rasprema broda duže od mjesec dana; zbog teške povrede radne obveze Pomorca (taksativno određene „povrede“) i prema propisanom postupku; , tri ili više uzastopnih lakših povreda radne obveze" (reklo bi se "zbog skrivljenog ponašanja radnika“); u slučaju "nesposobnosti Pomorca da stručno i kvalitetno obavlja poslove i radne zadatke" uz ${ }^{29}$ Kolektivni ugovor - čl. 26.; "Opći dodatak (2)“ MLC-a.

${ }^{30}$ Poslodavac se javlja kao jamac ako je „presuđeno" da je dužnik: upisani vlasnik broda ili Brodar, voditelj broda (ship's manager) ili agent za popunjavanje brodskih posada (čl. 27., st. 2. i čl. 1. Kolektivnog ugovora). V. i čl. 5. Pomorskog zakonika-cit. ${ }^{31}$ Kolektivni ugovor - cit. čl. 3. i 23.

32 Radi se o standardima prema: SOLAS konvenciji; LL-teretnoj liniji (1966.); STCW konvenciji; MARPOL-u; Konvenciji ILO 147 o minimalnim standardima (1976.).

${ }^{33}$ Radi se o postupanju Poslodavca u vezi s čl. 34. „Postupci po prigovoru“ ovoga Kolektivnog ugovora. propisani postupak i mogućnost „drugog posla“ i „novog“ ugovora. Posebno je reguliran postupak „raskidanja ugovora sa zapovjednikom" (i slučajevi). Propisani su slučajevi i postupak za ostvarivanje prava Pomorca "na naknadu od dvije osnovne mjesečne plaće" pri određenom raskidu ugovora, a posebno slučajevi kada se „odbijanje izvršenja ugovora... neće smatrati za loše vladanje Pomorca“.34

\section{UGOVORNE I DRUGE ODREDBE / Contractual and other provisions}

Kolektivni ugovor nije "označio" "normativni“, niti "ugovorni dio", ali se to iz sadržaja njegovih odredbi zaključuje. Neke od njih imaju i normativni i ugovorni karakter, kao npr. odredbe čl. 30. o „Brodskom odboru za sigurnost"; čl. 31. „Fond solidarnosti i naknade“; čl. 33. "Ništavost odricanja od prava"; čl. 36. „Postupanje protivno Kolektivnom ugovoru“; čl. 37. „Mjerodavno pravo i rješavanje sporova“.

Prema "naslovu" i "sadržaju", ugovorne su odredbe Kolektivnog ugovora u čl. 38., 39., 40., 41., 42. i 43.35

\subsection{Izmjene i dopune Kolektivnog ugovora / Addenda to the Collective Agreement}

Najmanje jedanput godišnje "sindikat i poslodavac razmatraju i ispituju uvjete Kolektivnog ugovora”, a ako se "zajednički dogovore... te će se izmjene i dopune sklopiti pisanim putem... i uključiti kao sastavni dio Kolektivnog ugovora“. Svaka ugovorna strana u pisanom obliku može predložiti „postupak obnove, izmjene ili dopune... uz uvjet da rok usuglašavanja ne bude duži od 60 dana od dana podnošenja prijedloga“ (čl. 38.).

\subsection{Trajanje Kolektivnog ugovora / Duration of the Collective Agreement}

Kolektivni ugovor zaključuje se razdobljem „od dvije godine od potpisivanja" (10. prosinca 2018.), a primjenjuje se od 1. siječnja 2019.;, ako nakon isteka razdoblje na koje je zaključen... ni jedna strana ne otkaže Kol. ugovor, njegova se valjanost produžuje do otkaza ili zaključivanja novog Kolektivnog ugovora“ (čl. 39.).

\subsection{Nadzor primjene. Rješavanje sporova / Supervision of implementation. Handling of disputes}

U odredbama čl. 40. Kolektivnog ugovora uređeno je: ovlašteni predstavnici sindikata/ITF-a mogu posjetiti i pregledati svaki Brod "radi nadziranja primjene Kol. ugovora" na kojem "mogu biti zaposleni članovi sindikata“; na zahtjev sindikata/ITF-a poslodavac će dati sve podatke (evidencije), „,uključujući i platne liste Pomoraca“; sporovi se rješavaju sporazumom strana ili u nedostatku sporazuma "sukladno zakonu“" ${ }^{\prime 36}$.

\subsection{Evidentiranje i odobrenje Kolektivnog ugovora / Registration and approval of the Collective Agreement} Kolektivni ugovor prijavljuje se nadležnom ministarstvu i javno se objavljuje u službenom glasilu Republike Hrvatske. „Kolektivni ugovor treba uputiti na odobrenje ITF-u. ${ }^{137}$

\footnotetext{
${ }^{34}$ V. Zakon o radu - cit. čl. 112. - 130.

${ }^{35}$ "Izmjene i dopune Kolektivnog ugovora"; "Trajanje Kolektivnog ugovora“; "Nadzor primjene Kolektivnog ugovora i rješavanje sporova“; „Evidentiranje odobrenje Kolektivnog ugovora“; „Primjena Kolektivnog ugovora na Ugovore o zaposlenju“ i „,Početak primjene Kolektivnog ugovora“

${ }^{36}$ V. Zakon o radu - cit. čl. 206., 208., 209. - 212.

${ }^{37}$ Kolektivni ugovor - cit. čl. 41., a "ne može se koristiti i/ili umnožavati bez prethodnog odobrenja sindikata i/ili ITF-a i Udruge".
} 


\subsection{Primjena Kolektivnog ugovora na Ugovore o zaposlenju / Application of the Collective Agreement to Employment Agreements}

Kolektivne ugovore „primjenjuje se na sve Ugovore o zaposlenju uključujući i one koji su zaključeni prije stupanja na snagu Kolektivnog ugovora“ (valjda samo na one koji još „traju“).

Zaključen je na hrvatskom i engleskom jeziku, a u „slučaju neusklađenosti... za njegovo tumačenje i primjenu mjerodavan je hrvatski tekst" (tekst na hrvatskom jeziku) (čl. 42.).

\subsection{Početak primjene / Entry into force}

"Ovaj Kolektivni ugovor stupa na snagu i primjenjuje se od 1. siječnja 2019. godine i vrijedi do 31. prosinca 2020. godine" (čl. 43.). Ovo kolidira s čl. 39. jer se govori o potpisivanju (10. prosinca 2018.).

\section{7. „Druge" odredbe / "Other" provisions}

Kako je već napisano, u Kolektivnom ugovoru, pored navedenih, sadržane su i "druge" odredbe karakteristične za radni status pomoraca i odnose u međunarodnoj plovidbi.

„Brodski odbor za sigurnost" (čl. 30.) jest obvezno tijelo na brodu, izravno "vezano" za upravu. Zadaća mu je zaštita zdravlja, sigurnost na brodu i osiguranje časnika za sigurnost s propisanom svrhom. Pravo je posade da u Odbor „izabere predstavnika za sigurnost sa propisanim ovlastima".38

U čl. 31. uređeno je pitanje „komunikacije i informiranja članova posade Broda ("komunikacija pomorca s obitelji", dostava glasila sindikata, korištenje Internetom "u skladu s internim aktom Poslodavca").

„Fond solidarnosti i naknade“ uređen je odredbama čl. 32. a odnose se na obvezu Poslodavca da uplati „iznose po članu posade broda godišnje sukladno Općem dodatku (2) u ITF Međ. fond... kada se radi o Brodovima pod zastavom pogodnosti ili u SPH fond... kada se radi o brodovima pod hrvatskom zastavom". „Poslodavac priznaje pravo sindikatu da djeluje... u skladu s ILO konvencijama br. 87. i $98 . "$

Smatrat će se činom "nedoličnog ponašanja“ kršenje prava pomoraca na rad, red $\mathrm{i}$ „život u okruženju bez prijetnji i zlostavljanja bilo s osnova spola, rase ili iz drugih motiva“" (čl. 33).

„Postupci po prigovoru“ uređeni su čl. 34., stoga se „bilo koji prigovor Pomorca rješava u dobroj vjeri... sukladno Pravilu 5.1.5.... MLC-a" i proceduri Poslodavca s kojom je Pomorac upoznat "prilikom zaključivanja ugovora o zaposlenju“.

Ništetna je svaka izjava Pomorca o "odricanju svojih prava iz Kolektivnog ugovora i Ugovora o zaposlenju... kojom se ta prava umanjuju ili povećavaju obveze“ (čl. 35.).

„Sindikat, ITF i/ili svaki Pomorac imaju pravo poduzeti mjere protiv Poslodavca" ako postupa protivno Kolektivnom ugovoru (čl. 36.).

Prema odredbama čl. 37., „Ugovor o zaposlenju podliježe primjeni hrvatskog prava" (određeni su i sporovi na koje se to odnosi i pitanje prethodnog postupka - „pregovorima“, u postupku mirenja, prije čega "ne mogu pokrenuti arbitražni ili sudski postupak"). Mirenje provode miritelji putem Centra za mirenje Hrvatske udruge za mirenje, Zagreb (HUM). Tek nakon neuspješnog mirenja može se voditi arbitražni ili sudski postupak. Popis arbitara utvrđen je u „Općem dodatku (6) Kol. ugovora“. U ostalim je odredbama postupak precizno utvrđen.

\section{ZAKLJUČAK / Conclusion}

8.1. Od 1. siječnja 2019. godine primjenjuje se Nacionalni Kolektivni ugovor za hrvatske pomorce na brodovima u međunarodnoj plovidbi (2019. - 2020.), zaključen između Hrvatske udruge brodara Mare Nostrum i Sindikata pomoraca Hrvatske/članka Međunarodne federacije transportnih radnika (ITF), a vrijedi za "sve hrvatske pomorce ili pomorce državljane Republike Hrvatske koji imaju boravište (rezident) ili prebivalište u Republici Hrvatskoj, a koji plove na brodovima u međunarodnoj plovidbi upisanim u hrvatski ili neki drugi upisnik brodova", ali i za pomorce državljane ostalih država članica Europske unije (EU).

8.2. Od zaključivanja ugovora o zaposlenju, od ukrcanja do iskrcanja, odnosno prestanka toga ugovora pomorac ima prava iz ovoga Kolektivnog ugovora u skladu s međunarodnim, regionalnim i nacionalnim propisima (što je Kolektivnim ugovorom naglašeno) s izraženim javnopravnim karakteristikama.

$U$ tom smislu zahtijeva se primjena konvencija: o radu pomoraca (MLC, 2006. i 2014.); SOLAS; o teretnoj liniji (LL) iz 1966.; STCW Konvencija; MARPOL; Konvencije br. 147 (1976.); ISM Kodeksa; konvencija 87. i 98. (ILO, 1948., 1949.) i drugih.

8.3. Posebna karakteristika ovoga Kolektivnog ugovora nalazi se u „Općim dodacima” (1), (2), (3), (4), (5) i (6) i „Posebnim dodacima“ uz Kolektivni ugovor pri Poslodavcu, a ti „Posebni dodaci" odnose se i primjenjuju samo ondje gdje su zaključeni. "Opći dodaci" sastavni su dio i primjenjuju se uz njegove pojedine odredbe koje se odnose na: nacionalne blagdane; novčane naknade; naknade za tjelesno oštećenje; Ugovor o zaposlenju pomorca; lista miritelju i lista arbitara.

„Posebni dodaci“ jesu: Lista brodova; Platna ljestvica; Isplata plaće; Trajanje ukrcaja; Obiteljska doznaka; Brojni sastav posade broda; Doprinosi za osiguranja i drugi.

\section{PROPISI / Rules and regulations}

Konvencija o radu pomoraca iz 2006. Zakon o potvrđivanju. NN, MU, 11/09

Međunarodna konvencija o zaštiti ljudskog života na moru (1974). NN, MU, 13/99, 4/00

Pomorski zakonik. NN, 181/04 do 26/15

Učur, Marinko (1997). Pomorsko radno pravo. Rijeka: Pravni fakultet.

Učur, Marinko (2003). Radnopravni status pomoraca. Rijeka: Pravni fakultet.

Uredba (EZ) br. 883/2004 Europskog parlamenta i Vijeća od 29. travnja 2004. o koordinaciji sustava socijalne sigurnosti

Zakon o obveznim odnosima. NN, 35/05 do 78/15

Zakon o radu. NN, 93/14, 127/17

Zakon o reprezentativnosti udruga poslodavaca i sindikata. NN, 93/14, 26/15

Zakon o zaštiti na radu. NN, 71/14 do 95/18

Ostali propisi i literatura navedeni su u bilješkama. 